\title{
ANALISIS KADAR FORMALIN PADA PERALATAN MAKAN MELAMIN YANG DIPERJUALBELIKAN DI KOTA MAKASSAR
}

\author{
Rahmawati ${ }^{1)}$ \\ 1) Akademi Analis Kesehatan Muhammadiyah Makassar \\ Alamat Korespondensi: rahmawatiamma60@gmail.com
}

\begin{abstract}
Abstrak
Melamin merupakan suatu polimer, yaitu hasil persenyawaan kimia (polimerisasi) antara monomer formalin dan fenol yang sangat rentang terhadap air panas sehingga memicu timbulnya formalin pada peralatan makan. Standar Nasional Indonesia (SNI) menyatakan bahwa kandungan formalin yang diperbolehkan pada peralatan makan melamin adalah sebesar 2 ppm. Penelitian ini bertujuan untuk mengetahui kadar formalin pada peralatan makan melamin yang diperjualbelikan di Kota Makassar. Penelitian ini bersifat deskriptif dimana sampel diambil secara purposive sampling dan menggunakan metode spektrofotometri. Hasil penelitian menunjukkan bahwa pada peralatan makan melamin yang berbeda-beda pada sampel yaitu 3 mangkok melamin dan 2 gelas dengan kadar formalin masing-masing 79,77 ppm, 9,64 ppm, 88,98 ppm, 59,92 ppm, dan 41,12 ppm. Dari penelitian ini dapat disimpulkan bahwa semua peralatan makan tersebut melebihi kadar standar formalin yang ditentukan.
\end{abstract}

Kata kunci: Formalin, Melamin, Spektrofotometer UV-Vis

\section{PENDAHULUAN}

Salah satu industri yang memanfaatkan bahan kimia dalam proses produksinya adalah industri peralatan rumah tangga yang sering digunakan dalam kehidupan sehari-hari sebagai wadah makanan dan minuman seperti piring, gelas, mangkok dan peralatan makan lainnya. Peralatan makan, minum dan masak banyak dijumpai dalam kehidupan sehari-hari terbuat dari berbagai jenis bahan. Salah satunya adalah melamin. Produk pecah belah melamin begitu banyaknya sehingga barang ini tak hanya bisa dibeli di toko tertentu, tetapi juga di pasar tradisional.

Peralatan makan yang terbuat dari melamin di satu sisi menawarkan banyak kelebihan. Selain desain warna yang beragam dan menarik, fungsinya juga lebih unggul dibanding peralatan makan lain yang terbuat dari keramik, logam, atau kaca. Melamin lebih ringan, kuat, dan tak mudah pecah. Harga peralatan melamin pun relatif lebih murah dibanding yang terbuat dari keramik (Harjono, 2006).

Namun dibalik kelebihannya, sebagian orang tidak menyadari bahwa melamin berpotensi membahayakan kesehatan manusia karena melamin menghasilkan monomer beracun yang disebut formalin. Pengguna yang mengkonsumsi makanan atau minuman panas yang sudah terkontaminasi formalin secara terus menerus, lambat laun dapat mengakibatkan kerusan hati, ginjal dan jantung dan dalam jangka panjang dapat berpeluang terkena penyakit kanker karena formalin bersifat karsinogenik (Imam, 2007).

Berdasarkan hasil penelitian sebelumnya antara Yayasan Lembaga konsumen Indonesia (YLKI) dan UI dari penelitian hasil rebusan air berbagai merek melamin diketahui kandungan formalin dalam perkakas melamin tersebut mencapai 4,76 - 9,22 mg/l (Nurheti, 2007).

Dari hasil penelitian di atas, menunjukkan bahwa melamin sangat rentan terhadap air panas sehingga memicu timbulnya formalin pada peralatan makan melamin tersebut. Kadar formalin yang dilepaskan peralatan melamin tersebut menunjukkan angka yang mencengangkan kerena tidak sesuai dengan standar acuan ISO 14528-3 tahun 1999 dan Standar Nasional Indonesia (SNI) yang menyatakan bahwa kandungan formalin yang diperbolehkan pada peralatan makan melamin adalah sebesar 2 ppm. Dan batas aman formalin 
menurut IPCS (International Programme on Chemical Safety). Ambang batas aman di dalam tubuh adalah 2 miligram per liter.

Melamin merupakan suatu polimer, yaitu hasil persenyawaan kimia (polimerisasi) antara monomer formalin dan fenol. Apabila kedua monomer itu bergabung, maka sifat toxic dari formalin akan hilang karena telah terlebur menjadi satu senyawa, yakni melamin (Nurheti, 2007).

Berdasarkan uraian dan fakta di atas, maka penulis akan melakukan penelitian dengan judul "Analisis Kadar Formalin pada Peralatan Makan Melamin yang Diperjualbelikan Di Kota Makassar".

\section{METODE PENELITIAN}

Alat dan Bahan

Alat yang digunakan adalah mortir, alat destilasi, pipet tetes, gelas kimia, gelas ukur, neraca analitik, dan spektrofotomter.

Bahan yang digunakan adalah mangkok melamin, gelas melamin, aquadest, asam fosfat pekat $\left(\mathrm{H}_{3} \mathrm{PO}_{4}\right)$, dan $\mathrm{H}_{2} \mathrm{SO}_{4}$.

\section{Prosedur Kerja}

\section{Penyediaan sampel melamin}

Sampel melamin diambil masingmasing peralatan makan melamin kemudian dihancurkan dengan mortir, dihancurkan lalu ditimbang. Sebanyak $5 \mathrm{~g}$ sampel ini dimasukkan kedalam labu destilasi, lalu ditambahkan $100 \mathrm{ml}$ aquadest dan $20 \mathrm{ml}$ asam fosfat pekat $\left(\mathrm{H}_{3} \mathrm{PO}_{4}\right)$. Alat destilasi dipasang hingga diperoleh volume destilasi sebanyak 20 $\mathrm{ml}$ yang ditampung di dalam erlenmeyer yang berisi $25 \mathrm{ml}$ aquadest (ujung pendingin harus dicelup ke dalam aquadest).

\section{Cara uji sampel}

Sampel yang sudah didestilasi diencerkan dalam $200 \mathrm{ml}$ aquadest, kemudian ditambahkan 1 tetes reagen 1 $\left(\mathrm{H}_{2} \mathrm{SO}_{4}\right)$ dan 1 mikrospoon reagen 2 akan menghasilkan larutan berwarna ungu. Masukan larutan ke dalam kuvet, diamkan selama 10 menit untuk dianalisis kadar formalinnya.
Analisis kadar formalin metode spektrofotometri (SOP BBLK, 2014).

Setelah dilakukan destilasi terhadap sampel, kandungan formalin pada larutan tersebut diukur absorbance pada spektrofotometri UV-VIS.

\section{HASIL DAN PEMBAHASAN}

Pengambilan sampel dilakukan secara purposive sampling pada beberapa toko alat rumah tangga dari berbagai merek peralatan makan melamin di kota Makassar. Sampel selanjutnya ke Balai Besar Laboratorium Kesehatan (BBLK) Makassar untuk dilakukan penelitian.

Analisis kadar formalin pada peralatan makan melamin berbeda-beda pada sampel 3 mangkok melamin dan 2 gelas yang hasilnya dapat dilihat pada tabel berikut:

Tabel 1. Hasil analisis kadar formalin pada peralatan makan mangkok dan gelas melamin

\begin{tabular}{lc}
\hline \multicolumn{1}{c}{ Sampel } & Hasil $(\mathrm{ppm})$ \\
\hline Mangkok merah & 79,77 \\
Mangkok putih & 9,64 \\
Mangkok Orange & 88,98 \\
Gelas biru & 54,92 \\
Gelas merah & 41,12 \\
\hline
\end{tabular}

Berdasarkan tabel 1 dapat diketahui bahwa pada sampel mangkok merah hasil analisis kadar formalinnya 79,77 ppm, mangkok putih hasil analisis kadar formalinnya 9,64 ppm, mangkok orange hasil analisis kadar formalinnya 88,98 ppm, gelas biru hasil analisis kadar formalinnya 59,92 ppm, dan gelas merah hasil kadar analisis formalinnya 41,12 ppm semua melebihi kadar standar formalin yang ditentukan.

Munculnya formalin kerena hasil penguapan destilasi. $\mathrm{CH}_{2} \mathrm{O}$ direaksikan dengan $\mathrm{H}_{3} \mathrm{PO}_{4}$ pada suhu $90^{\circ}-100^{\circ} \mathrm{C}$ akan menguap menghasilkan wujud gas. Alat kondensor digunakan pada peristiwa kondensasi untuk mengubah wujud gas menjadi cair.

Formalin dalam wujud cair ditambahkan asam sulfat menghasilkan warna ungu pekat yang menandakan kosentrasi formalinya sangat tinggi 
sehingga dilakukan faktor pengenceran 10.000 dengan mencampurkan formalin sebanyak 0,02 $\mathrm{ml}$ dalam $200 \mathrm{ml}$ aquades dan faktor pengenceran 40.000 dengan mencampurkan formalin sebanyak 0,005 $\mathrm{ml}$ dalam $200 \mathrm{ml}$ aquades sampai menghasilkan ungu yang lebih muda. Munculnya formalin pada sampel peralatan makan melamin kemungkinan disebabkan jenis bahan pembuatannya yang bukan dari melamin asli yang termasuk kategori food grade atau aman untuk makanan dan minuman.

Munculnya formalin dengan kadar yang bervariasi pada peralatan makan melamin disebabkan karena formalin sebagai bahan perekat dan pewarna. Semakin tinggi kadar formalin yang digunakan akan menghasilkan peralatan makan melamin yang tidak mudah retak dan warnanya akan semakin cerah.

Efek akut yang ditimbulkan apabila konsumen mengkonsumsi makanan atau minuman yang sudah mengandung formalin dalam jumlah yang banyak, maka efek yang langsung terlihat adalah iritasi, alergi, sakit kepala, mual, muntah, sakit perut dan diare. Pada konsentrasi yang sangat tinggi dapat menyebabkan kematian (Amiruddin, 2006). Dan apabila konsumen mengkonsumsi makanan atau minuman yang sudah mengandung formalin dalam jangka waktu yang lama atau berulang-ulang melebihi batas yang telah ditentukan, mungkin untuk saat ini belum merasakan akibatnya, tetapi efek dari formalin baru terasa beberapa tahun kemudian karena formalin bersifat karsinogen, dan jika terpapar secara terus menerus dapat mengakibatkan kerusakan pada hati, ginjal dan jantung. Jika kandungan formaldehid dalam tubuh tinggi, akan bereaksi secara kimia dengan hampir semua zat di dalam sel, sehingga menekan fungsi sel dan menyebabkan kematian sel dan menganggu ekspresi yang normal, yang mengakibatkan rusaknya gen-gen yang diwariskan sehingga melahirkan generasi dengan cacat gen (Amiruddin, 2006).
Masuknya formalin dalam tubuh kita dalam jumlah batas yang berlebih akan membahayakan kesehatan karena terjadi akumulasi formalin di dalam tubuh manusia sehingga sangat berbahaya pada tubuh manusia.Tetapi, dalam jumlah sedikit, formalin akan larut dalam air, serta akan dibuang ke luar bersama cairan tubuh. Imunitas tubuh sangat berperan dalam berdampak tidaknya formalin di dalam tubuh.Jika imunitas rendah atau mekanisme pertahanan tubuh rendah, sangat mungkin formalin dengan kadar rendahpun bisa berdampak buruk terhadap kesehatan.

\section{KESIMPULAN}

Berdasarkan hasil analisis kadar formalin peralatan makan melamin pada gelas dan mangkok yang diperjualbelikan di kota Makassar maka diperoleh kesimpulan yaitu pada sampel mangkok merah 79,77 ppm, mangkok putih $9,64 \mathrm{ppm}$, mangkok orange 88,98 ppm, gelas biru 59,92 ppm, dan gelas merah 41,12 ppm, semua sampel melebihi 2 ppm standar kadar formalin yang ditentukan.

\section{SARAN}

Disarankan bagi masyarakat kota Makassar sebaiknya harus lebih teliti dalam memilih produk peralatan makan melamin dengan melihat label yang bertuliskan food grade karena kandungan formalinnya lebih sedikit dibandingkan dengan produk non food grade dan bagi konsumen sebaiknya tidak menggunakan peralatan makan melamin dengan suhu yang tinggi karena formalin akan larut pada suhu 90- $100^{\circ} \mathrm{C}$.

\section{DAFTAR PUSTAKA}

Amiruddin, M. D. 2006. Formalin Dalam Makanan. Available from:

(http://www.freelists.org/archive s/ppi/012006/msg0209.html.

Harjono, Y. 2006. Makan Sehat Hidup Sehat, Jakarta : Kompas Hopp, Vollrath, 1983. Handbook of Applied Chemistry, Hemisphere Publishing Corporation. Washington. 
Horwitz, W. 1970. Official Method of Analysis of Official Analytical Chemist, Fifteenth Edition. Washington DC: Station Washington DC.

Imam, S. 2007. Perkakas Makan dari Melamin. Jakarta : Bisnis Indonesia.

Windholz, dkk, 1976. The Merck Index An Encyclopedia of Chemicals and Drugs Ninth Edition. USA: Merck \& CO. Inc.

Yuliarti, N. 2007. Awas! Bahaya di Balik Lezatnya Makanan. Yogyakarta: CV Andi. 